\title{
Penerapan Metode Two Stay Two Stray Dalam Meningkatkan Pemahaman Sistem Pernafasan pada Siswa SMP N 2 Gunung Sahilan
}

\author{
YULKASRI \\ Dinas Pendidikan Kabupaten Kampar \\ SMP Negeri 2 Gunung Sahilan \\ E-mail : yulkasrismp2@gmail.com
}

\begin{abstract}
The Two Stay Two Stray method becomes a method in which learning in order to improve student understanding in learning. The teacher will continue to try to learn and apply various methods to make students successful in learning. As learning the respiratory system in science lessons, it becomes a challenge where teachers always face obstacles in making students succeed in achieving the established KKM. Through the method of classroom action research, applying this method and analyzed using qualitative methods. The results show that the application of the two stay two stray method can improve students' understanding of the respiratory system.
\end{abstract}

Keywords: Two Stay Two Stray Method, Understanding of the Respiratory System

Makhluk hidup di dunia ini sangat beragam, baik tumbuhan maupun hewan. Hal ini mendorong para ahli untuk mempelajarinya lebih lanjut,dengan suatu sistem yang disebut klasifikasi. Klasifikasi ini, memungkinkan para ahli lebih mudah mempelajari makhluk hidup yang sangat beragam itu. Dasar klasifikasi makhluk hidup ini adalah adanya persamaan dan perbedaan ciri-ciri morfologi, anatomi, fisiologi, tingkah laku, dan lain-lain.

Untuk mempelajari lebih lanjut, kita dapat mengamati beberapa contoh hewan dan tumbuhan. Berdasar kesamaan ciri, kita dapat mengklompokan atau mengklasifikasikannya. Kegiatan pengklasifikasikan makhluk hidup bertujuan untuk memeprtmudag mengenal objek yanng beraneka ragam dengan cara mencari persamaan dan perbedaan ciri serta sifat pada objek tersebut. Klasifikasi juga mempermudah dalam pemberian nama ilmiah terhadap suatu individu.

Saat ini lembaga pendidikan terus berupaya dan upaya utama yang harus dilakukan guru untuk meningkatkan mutu pendidikan adalah meningkatkan kualitas pembelajaran. Pembelajaran yang berkualitas adalah ujung tombak yang menentukan tercapainya sasaran dan tujuan pendidikan secara efektif, efisien, kreatif produktif dan bermutu.

Dalam membelajarkan siswa, guru diharapkan mengembangkan semua potensi siswa dengan berbagai pengetahuan dan pengalaman bermakna. Pemberian pengalaman yang bermakna bagi siswa dalam pembelajaran di sekolah harus direncanakan secara sadar dan sistematis karena pengalaman siswa tersebut harus dapat direncanakan, diterapkan, dan dievaluasi ketepatannya dalam dunia nyata.

Mata pelajaran Ilmu Pengetahuan Alam merupakan salah satu mata pelajaran yang membutuhkan kerjasama yang baik antara siswa dan guru dalam upaya melakukan transfer pengetahuan dan pemahaman kepada siswa. Selama ini mata pelajaran IPA selalu dilakukan dengan model pembelajaran yang monoton dan membosankan bagi siswa dan guru sepertinya tidak ada cara lain untuk memberikan ilmu dan pemahaman kepada siswa.

Hal ini memberikan dampak kepada siswa khususnya semangat atau motivasi belajarnya di kelas dan pada akhirnya akan berdampak kepada hasil belajar mata pelajaran IPA pada 
umumnya. Selain nilai KKM yang kurang memenuhi target juga ditambah dengan sikap perilaku siswa yang kurang memahami dan kurang mengerti apa arti pentingnya materi pelajaran yang diberikan kepadanya.

Khususnya pada topik pembelajaran keanekaragaman mahluk hidup siswa masih belum memiliki pemahaman yang baik, hal ini dapat dilihat dari capaian pembelajaran siswa yang belum memenuhi KKM. Berdasarkan data yang berhasil dihimpun, diketahui bahwa dari 26 siswa KKM 70, ketuntasan hanya mencapai 50\%, sedangkan $50 \%$ sisanya belum tuntas.

Berdasarkan pada uraian di atas, maka pada kesempatan ini saya tertarik melakukan penelitian tindakan kelas dengan menerapkan metode pembelajaran two stay two stray dalam rangka meningkatkan hasil belajar siswa dalam belajar mata pelajaran keanekaragaman mahluk hidup khususnya sub materi pelajaran keanekaragaman mahluk hidup.

Pada penelitian ini definisi operasionalnya adalah: Perbedaan makhluk hidup disebabkan bentuk tubuh, susunan tubuh, dan kebiasaan bertingkah lauku yang berbeda. Perbedaan-perbedaan tersebut mengakibatkan makhluk hidup beraneka ragam. Makhluk hidup yang beraneka ragam dapat dikelompokan berdasarkan kesamaanya. Model two stay two stray merupakan salah satu metode yang tepat untuk membelajarkan siswa secara berkelompok dan saling bekerja sama/membantu. Pada mata pelajaran Ilmu Pengetahuan Alam, pembelajaran kooperatif ini diharapkan siswa dapat bekerja sama dalam memperluas pemahaman konsep Ilmu Pengetahuan Alam secara menyeluruh.

Slameto (2003) mengatakan bahwa belajar adalah suatu proses usaha yang dilakukan seseorang untuk memperoleh suatu perubahan tingkah laku yang baru secara keseluruhan, sebagai hasil pengalaman sendiri dalam interaksi dengan lingkungannya. Pendapat tersebut menyatakan bahwa belajar bertujuan untuk mengadakan perubahan yang dikehendaki dalam tingkah laku, ilmu pengetahuan dan keterampilan seorang siswa. Pembelajaran pada hakekatnya adalah proses interaksi antara peserta didik dengan lingkungannya, sehingga terjadi perubahan tingkah laku ke arah yang lebih baik (Mulyasa, 2005). Perubahan yang dikehendaki dalam penelitian ini adalah peningkatan hasil belajar Ilmu Pengetahuan Alam siswa.

Dimyati dan Mudjiono (2002) mengatakan bahwa hasil belajar adalah hasil yang dicapai dalam bentuk angkaangka atau skor setelah diberikan tes hasil belajar pada setiap akhir pembelajaran. Lebih lanjut Djamarah (1994) menyatakan bahwa hasil belajar adalah hasil penilaian pendidik terhadap kemajuan siswa setelah dilakukan proses pembelajaran. Berdasarkan pengertian hasil belajar dari beberapa pendapat di atas dapat disimpulkan bahwa hasil belajar adalah kemampuan yang dimiliki siswa yang dinyatakan dengan angka-angka atau skor yang didapat siswa dari hasil tes setelah mengikuti proses pembelajaran. Sedangkan Sudjana (2004) mengatakan bahwa hasil belajar adalah kemampuan yang dimiliki siswa setelah menerima pengalaman belajarnya. Hal ini menunjukkan bahwa hasil belajar adalah penguasaan yang dicapai siswa dalam mengikuti proses mengajar sesuai tujuan pendidikan yang ditetapkan (Nursito, 2002). Hakikat hasil belajar yang dapat mewujudkan tujuan pembelajaran matematika adalah perubahan tingkah laku yang mencakup kemajuan kognitif, kemampuan afektif, kemampuan psikomotoris (Sudjana, 2004).

Berdasarkan pengertian hasil belajar tersebut dapat disimpulkan bahwa hasil belajar Ilmu Pengetahuan Alam merupakan skor hasil belajar siswa melalui kegiatan penilaian atau pengukuran yang dapat diketahui setelah siswa melakukan suatu kegiatan belajar Ilmu Pengetahuan Alam. 
Dalam penerapan metode pembelajaran konstruktivisme, siswa diharapkan dapat membangun dan membentuk pengetahuannya sendiri, bukan menerima informasi sepihak dari seorang guru. Pembentukan pengetahuan tersebut dapat berasal dari diri yang bersifat individu, dapat pula diperoleh secara kelompok/bekerja sama dengan siswa lain. Dalam hal ini berkaitan dengan masyarakat belajar (Learning Community), model Two Stay Two Stray (TSTS) yang akhirnya melahirkan pendekatan pembelajaran kooperatif.

Pembelajaran kooperatif merupakan model pembelajaran yang mana siswa belajar dalam kelompok-kelompok kecil yang mempunyai tingkat kemampuan yang berbeda. Dalam melakukan tugas belajarnya, tiap anggota kelompok saling kerja sama dan membantu untuk memahami materi yang sedang dipelajari. Salah satu kelebihan pembelajaran kooperatif adalah memberikan siswa keterampilan untuk bekerja sama dan berkolaborasi dengan siswa lain, dengan berbagai kemampuan dan karakter yang berbeda.

Model pembelajaran kooperatif tidak sekedar belajar dalam kelompok, namun harus memenuhi unsur-unsur dasar pembelajaran kooperatif supaya pengelolaan kelas lebih efektif (Lie, 2004). Model pembelajaran ini bukan sekedar diskusi yang dikuasai/didominasi oleh beberapa orang saja, kebanyakan yang lain hanya suka menjadi penonton yang pasif. Namun disini guru harus mendorong siswa untuk berpartisipasi secara aktif dalam proses pembelajaran. Model pembelajaran ini merupakan salah satu bentuk penyajian materi yang menitikberatkan pada interaksi antaranggota kelompok untuk menyelesaikan tugas kelompok tertentu.

Strategi pembelajaran menjadi menarik dipelajari (Hadiyati, dkk (2017). Strategi ini sangat baik untuk kegiatan kerja kelompok yang bervariasi untuk memecahkan suatu permasalahan sosial yang sifatnya multidimensi. Dalam Diklat Review: Jurnal Manajemen Pendidikan dan Pelatihan pelaksanaan strategi ini, setiap kelompok diberi kesempatan untuk bertamu (berkunjung) ke kelompok lain, untuk berbagi informasi dan berbagi hasil kerja kelompoknya (Lie, 2004). Juga menurut Suroto (2017) bahwa penerapan metode pembelajaran ini akan semakin menjadi sebuah tuntutan bila ingin mencapai keberhasilan dalam pembelajaran siswa di sekolah.

\section{METODE}

Jenis penelitian yang digunakan dalam penelitian ini adalah menggunakan penelitian tindakan Refleksi tindakan yang diperoleh bisa berupa pemahaman terhadap praktik-praktik tersebut dan situasi yang melatarbelakangi praktik itu dilaksanakan. Penelitian tindakan kelas dilakukan secara kolaboratif, untuk kemantapan rasional dalam pelaksanaan tugas, serta memperbaiki kondisi tempat praktik pembelajaran sendiri di sekolah. Dalam penelitian ini yang menjadi subyek penelitian adalah siswa Kelas VII SMP N 2 Kampar Kiri Hilir. Jumlah siswa Kelas VII seluruhnya adalah 26 siswa. Penelitian ini dilaksanakan di Kelas VII SMP N 2 Kampar Kiri Hilir, untuk mata Pelajaran IPA pada materi pelajaran keanekaragaman mahluk hidup.

Metode pengumpulan data pada penelitian ini adalah observasi, tes, wawancara dan catatan lapangan. Model analisis data yang dipergunakan adalah reduksi data, penyajian data, penarikan simpulan, serta verifikasi refleksi.

\section{HASIL}

Hasil penelitian ini terbagi menjadi dua siklus, yang dimulai dari refleksi awal. Refleksi awal dilaksanakaan dengan melakukan pengamatan pendahuluan untuk mengetahui kondisi awal dilakukan oleh pengamat kelas, yakni rekan sejawat. Hasil refleksi awal dipergunakan untuk menetapkan dan merumuskan rencana tindakan yaitu menyusun strategi awal pembelajaran.

Kegiatan pembelajaran pelajaran

E-ISSN:2598-6449 P-ISSN: 2580-4111 Vol. 2, No. 2, Agustus 2018 
keanekaragaman mahluk hidup dapat disajikan dengan menggunakan strategi atau pendekatan dan penggunaan model two stay two stray dan dapat mengatasi permasalahan tersebut. Akhirnya kegiatan pembelajaran dapat berjalan dengan wajar, motivasi belajar siswa meningkat, dan pada akhirnya pestasi belajar siswa meningkat.

Berdasarkan pengamatan awal yang dilakukan oleh guru yang bertindak sebagai peneliti, pada saat berlangsungnya proses pembelajaran diperoleh data kondisi dan permasalahan pembelajaran yang terjadi pada siswa Kelas VII SMP N 2 Kampar Kiri Hilir kurang mampu mengingat pelajaran pelajaran keanekaragaman mahluk hidup sehingga siswa memiliki hasil belajar yang rendah.

Berdasarkan kondisi yang ada, maka peneliti merencanakan pembelajaran dengan two stay two stray, agar siswa mampu mengingat yang terjadi pada pelajaran keanekaragaman mahluk hidup dari penjelasan yang diberikan oleh guru di depan kelas dan dari buku Pelajaran IPA Kelas VII, sehingga prestasi belajarnya meningkat.

Pembelajaran dengan two stay two stray menekankan pada kegiatan aktif siswa, karena semua siswa terlibat dalam pembelajaran. Guru membagi siswa dalam kelompok berempat dan memberikan tugas kepada semua kelompok, kemudian setiap siswa memikirkan dan mengerjakan tugas tersebut sendiri. Siswa berpasangan dengan salah satu rekan dalam kelompok dan berdiskusi dengan pasangannya dan selanjutnya kedua pasangan bertemu kembali dalam kelompok berempat. Siswa mempunyai kesempatan untuk membagikan hasil kerjanya kepada kelompok berempat.

Pada kegiatan awal guru perlu terus-menerus memotivasi siswa agar aktif selama pembelajaran dengan memberikan penjelasan secara terus menerus mengenai pengertian mahluk hidup, Jenis mahluk hidup: mahluk hidup umum dan mahluk hidup tematik (khusus), bentuk mahluk hidup, mahluk hidup datar dan mahluk hidup timbul

Siswa melakukan kegiatan pembagian kelompok dan mendiskusikan pertanyaan kepada pasangan kelompok, sebagian ada yang mampu menyelesaikannya pada waktu yang ditentukan namun sebagian lainnya masih terlambat sehingga dalam penilaiannya masih belum maksimal dan capaiannya masih belum memadai karena siswa masih belum memahami secara baik metode yang diterapkan kepadanya. Hasil belajar siswa pada siklus pertama tampak Dari data tersebut di atas dapat diketahui bahwa 50\% siswa yang menerima pembelajaran pada siklus pertama masih belum tuntas dan ini menunjukkan bahwa perlu adanya perbaikan pada siklus berikutnya. Seperti telah diuraikan masalah penggunaan waktu yang cermat lebih jadi pertimbangan dalam menyelesaikan soal yang diberikan.

Pada siklus kedua guru harus lebih semangat kepada siswa untuk lebih berhasil, agar ketuntasan tercapai maksimal. Materi mahluk hidup dan kemudian melaksanakan kegiatannya. Siswa diajak keluar kelas untuk mengukur panjang dan lebar halaman sekolah, kemudian di tanyakan dapatkah halaman tersebut digambarkan pada kertas sesuai dengan ukuran yang sebenarnya. Hasil belajar siswa pada siklus kedua tampak hanya $80,8 \%$ saja siswa yang tuntas KKM dan ini berarti bahwa $19,2 \%$ siswa lainnya tidak tuntas materi yang diberikan, sehingga penerapan model masih dapat dilanjutkan dan memberikan kesimpulan.

Pada siklus ketiga guru harus lebih semangat kepada siswa untuk lebih berhasil, agar ketuntasan tercapai maksimal. Materi mahluk hidup dan kemudian melaksanakan kegiatannya. Siswa diajak keluar kelas untuk mengukur panjang dan lebar halaman sekolah, ditanyakan dapatkah halaman tersebut digambarkan pada kertas sesuai dengan ukuran yang sebenarnya. Hasil belajar siswa pada siklus kedua tampak hanya $15,4 \%$ saja siswa yang belum tuntas KKM dan ini berarti bahwa $84,6 \%$ siswa lainnya sudah tuntas materi yang diberikan, sehingga penerapan model sudah dapat dihentikan dan memberikan kesimpulan. 


\section{PEMBAHASAN}

Dalam pelaksanaan penelitian tindakan kelas pada materi pelajaran keanekaragaman mahluk hidup siswa yang diamati meliputi tanggapan siswa dalam memperhatikan penjelasan umum tentang metode two stay two stray, keterlibatan siswa dalam memikirkan jawaban, keberanian siswa dalam mencari pasangan dalam kelompok yang telah ditentukan, keberanian siswa dalam mendeskripsikan pelajaran keanekaragaman mahluk hidup dan kecepatan siswa dalam menyelesaikan pertanyaan.

Berdasarkan hasil pengamatan menunjukkan bahwa selama kegiatan belajar mengajar pada siklus pertama tanggapan siswa dalam memperhatikan penjelasan umum tentang metode two stay two stray dengan kategori cukup, keterlibatan siswa dalam memikirkan jawaban juga dalam kategori cukup, keberanian siswa dalam mencari rekan yang cocok juga baik, keberanian siswa dalam mendeskripsikan pelajaran keanekaragaman mahluk hidup masih cukup dan kecepatan siswa dalam menyelesaikan pertanyaan juga cukup.

Selama kegiatan belajar mengajar pada siklus kedua tanggapan siswa dalam memperhatikan penjelasan umum tentang metode two stay two stray dengan kategori baik, keterlibatan siswa dalam memikirkan jawaban juga dalam kategori baik, keberanian siswa dalam mencari rekan yang cocok juga cukup, keberanian siswa dalam mendeskripsikan pelajaran keanekaragaman mahluk hidup baik dan kecepatan siswa dalam menyelesaikan pertanyaan juga baik.

\section{SIMPULAN}

Berdasarkan hasil penelitian tindakan kelas pada Kelas VII pada mata Pelajaran IPA sub bahasan pelajaran keanekaragaman mahluk hidup dapat disimpulkan. Setelah penerapan metode two stay two stray kepada siswa pada sub bahasan penggunaan mahluk hidup terus mengalami peningkatan pemahaman dan juga adanya perubahan perilaku siswa dalam mengikuti pelajaran dan cara guru melaksanakan metode pembelajaran semakin baik. Melalui penerapan metode two stay two stray terbukti bahwa dapat meningkatkan hasil belajar penggunaan mahluk hidup.

\section{DAFTAR RUJUKAN}

Dimyati dan Mudjiono. 2002. Belajar dan Pembelajaran. Jakarta: Rineka Cipta dan Depdikbud

Djamarah. 1994, Prestasi Belajar dan Kompetensi Guru. Surabaya : Usaha Nasional

Hadiyati, H., \& Fatkhurahman, F. (2017). Pelatihan Penulisan Jurnal Ilmiah Bagi Tenaga Pendidik (Guru SD) Di Kecamatan Siak Hulu Kabupaten Kampar. Jurnal Diklat Review, 1(1), 18-24.

Lie, Anita. 2004. Cooperative Learning. Grasindo. Jakarta

Mulyasa E, 2005, Menjadi guru professional, menciptakan pembelajaran kreatif

Nursito. 2002. Peningkatkan Prestasi Sekolah Menengah. Insan Cendekia, Jakarta

Slameto, 1991, Proses belajar mengajar dalam sistem kredit semester (SKS) Jakarta: Bumi Aksara

Sudjana, Nana. 2004. Dasar-dasar Proses Belajar Mengajar. Bandung :Sinar Baru Algensido Offset.

Suroto, B., Novita, N., Pailis, E. A., Waldelmi, I., \& Fatkhurahman, F. (2017). Metode Penelitian Tindakan Solusi Bagi Masalah Sosial. Jurnal Diklat Review, 1(1), 25-28. 